\title{
THE POTENTIAL BIOACTIVITY OF THE WILD GROWN ROSEHIP (Rosa canina L.) AND POMEGRANATE (Punica granatum L.)
}

Staniša Latinović, Mirjana Brkljača, Marina Vujasin, Zoran Kukrić*, Božana Odžaković

Faculty of Technology, University of Banja Luka, Banja Luka, Bosnia and Herzegovina
(ORIGINAL SCIENTIFIC PAPER) UDC 547.565:615.322:616.379-008.64 DOI: $10.5937 /$ savteh2002014L
The aim of this study was the determination of the antioxidant and antihyperglycemic effect of wild grown rosehip and pomegranate fruit extracts, and the determination of the polyphenolic content (total phenols, flavonoids, flavonols, flavan-3-ols and total and monomeric anthocyanins). The antioxidant activity of rosehip fruit in view of stable DPPH and ABTS radicals was higher comparing to pomegranate fruit, while according to the $\mathrm{OH}$ radical these two samples showed a similar effect (94.17 and $92.03 \mu \mathrm{g} / \mathrm{mL})$. A dry rosehip fruit extract was found to have a 1.6 times more pronounced antihyperglycemic activity $(1.42 \mathrm{mg} / \mathrm{mL})$ compared to the dried pomegranate fruit extract $(2.26 \mathrm{mg} / \mathrm{mL})$. The content of total phenols of rosehip fruit was $8.75 \mathrm{mg} \mathrm{GAE} / \mathrm{g}_{\mathrm{FPM}}$ and $22.01 \mathrm{mg} \mathrm{GAE} / \mathrm{g}_{\mathrm{DPM}}$, higher than the content of total phenols of pomegranate fruit ( $3.44 \mathrm{mg}$ GAE/g $/ \mathrm{FPM}_{\mathrm{F}}$ and $15.43 \mathrm{mg}$ GAE/gDPM). The content of total phenols in rosehip and pomegranate fruits was higher than the content of total flavonoids, flavonols and flavan-3-ol and total and monomeric anthocyanins, which indicates that these components had the greatest impact on bioactivity of wiled grown fruits. Due to their bioactivity, the fruits of wild grown rosehip and pomegranate can be considered as potential functional food and food suitable for diabetics.
Keywords: polyphenolic components, antioxidativity, antihyperglycemic activity

\section{Introduction}

Daily consumption of fruits and vegetables provides for body essential nutrients, such as fibers and bioactive compounds, and reduces the risk of developing some chronic diseases [1]. Wild grown edible fruits may have the potential to confer beneficial health effects due to their bioactivity and polyphenolic compounds [2]. Rosehip (Rosa canina L.) belongs to the rose family (Rosaceae) and is a good source of bioactive compounds such as: vitamins, carotenoids, amino acids, organic acids, minerals, as well as phenolic compounds that show antioxidant, anticancer and antimutagenic effects [3-6]. Rosehip fruits are less often used fresh, but mainly during the industrial processing for marmalade, jelly, syrup, herbal tea and the wine production [7]. Wild grown pomegranate (Punica granatum L.) is considered to be one of the oldest edible fruit and it is classified in the family Punicaceae. The edible part of the pomegranate fruit are the arils (52\% of the fruit weight) comprising $78 \%$ juice and $22 \%$ seeds [8]). Fruits of wild grown pomegranate are good sources of many, for health beneficial compounds, such as tannins, anthocyanins, phenolic and organic acids [9].

a-glucosidase is an enzyme found in the small intestine of the human digestive tract and is involved in the final step of digestion of carbohydrates to glucose. People with the increased activity of this enzyme suffer from postprandial hyperglycemia that occurs after eating, when the blood glucose level is above $180 \mathrm{mg} / \mathrm{dL}$. Carbohydrates digestion and absorption slow down with the inhibition of a-glucosidase and the increase in the glucose levels after the meal decreases [10-12]. Studies have shown that polyphenolic compounds from fruit are effective $\alpha$-glucosidase inhibitors and able to cause an antihyperglycemic effect. In addition, polyphenolic compounds flavonoids, flavones, isoflavones and antocyanins show other bioactivities such as the antioxidant effect [13].

The aim of this study was the determination of the antioxidant and antihyperglycemic effect of wild grown rosehip and pomegranate fruit extracts, and the determination of the polyphenolic content (total phenols, flavonoids, flavonols, flavan-3-ols and total and monomeric anthocyanins).

\section{Experimental}

\section{Plant material}

Fully ripe, wiled grown fruits were picked manually in October 2019, rosehips (Rosa canina L.) at the locality of Rovine, the municipality of Gradiška, and pomegranates (Punica granatum L.) at the locality of Žegulja, the municipality of Stolac. The fruit samples were cleaned from inedible parts, homogenized in an electric mill and stored at $-18^{\circ} \mathrm{C}$ until analysis. The dry matter content of the fruits was determined according to the standard method [19].

\section{Preparation of the extracts}

The samples $(5 \mathrm{~g})$ were treated in an ultrasonic bath for 15 minutes and were extracted with $80 \%$ ethanol for 10 minutes

\footnotetext{
*Author address: Zoran Kukrić, Faculty of Technology, University of Banja Luka

Vojvode Stepe Stepanovića 73, 78000 Banja Luka, Bosnia and Herzegovina

E-mail: zoran.kukric@tf.unibl.org

The manuscript received: August, 3, 2020

Paper accepted: October, 16, 2020.
} 
each, with solvomodule $1: 10 \mathrm{~m} / \mathrm{v}$. The extraction procedure was performed in triplicate.

The solvent from the liquid extracts was removed by evaporation on a rotary evaporator. The resulting extracts were dried in a vacuum desiccator to constant weight and stored in the refrigerator at $+4{ }^{\circ} \mathrm{C}$ until the antihyperglycemic activity analysis.

The determination of total phenolic, flavonoid, flavonol,

flavan-3-ol and total and monomeric anthocyanins contents

Liquid ethanolic extracts were used for the determination of the content of total phenols, flavonoids, flavonols and flavan-3-ol and the antioxidant activity. For the antihyperglycemic effect determination, the obtained extracts were evaporated until dry. Total phenolics content was determined spectrophotometrically $(\lambda=765 \mathrm{~nm})$ by a modified FolinCiocalteu method [14]. The results were expressed as mg of gallic acid equivalent per gram of the fresh plant material (mg GAE/gFPM). The total flavonoids content was measured at $\lambda=420 \mathrm{~nm}$ as described by Ordon et al. [15]. The results were expressed as $\mathrm{mg}$ of quercetin hydrate equivalent per gram of the fresh plant material (mg Qc/gFPM). Total flavonols content was measured at $\lambda=510 \mathrm{~nm}$ by Kumaran and Karunakaran [16]. The results were expressed as mg of quercetin hydrate equivalent per gram of the fresh plant material (mg Qc/g $\left.g_{F P M}\right)$. Total flavan-3-ols content was measured at $\lambda=500 \mathrm{~nm}$ [17]. The results were expressed as $\mu \mathrm{g}$ of catechin equivalent per gram of the fresh plant material ( $\mu \mathrm{g}$ CAT/gFPM). To determine total and monomeric anthocyanins, 20 grams of the sample was extracted with the solution of $1.5 \mathrm{M} \mathrm{HCl}$ and $96 \%$ ethanol $(85: 15, \mathrm{v} / \mathrm{v})$ for 24 hours at $0^{\circ} \mathrm{C}$. The spectrophotometric $\mathrm{pH}$ differential method was used to determine monomeric and total (monomeric plus polymerized) anthocyanins [18]. Two dilutions of the sample were prepared in the $0.025 \mathrm{M} \mathrm{KCl}$ solution and in the $0.4 \mathrm{M}$ sodium acetate solution adjusted respectively to $\mathrm{pH} 1.0$ and 4.5 with $\mathrm{HCl}$. The absorbance of each dilution was measured at 520 and $700 \mathrm{~nm}$ against a distilled water blank. The contents of total and monomeric anthocyanins were expressed as mg of cyanidin-3-glucoside per gram of the fresh plant material (mg CyG/grPM).

Spectrophotometric measurements were performed on a UV-VIS spectrophotometer (PerkinElmer Lambda 25). In order to facilitate the comparison of our results with the literature data, the content of total phenols, flavonoids, flavonols, flavan-3-ols and total and monomeric anthocyanins of rosehip and pomegranate fruit samples were also calculated and expressed on the dry plant material (DPM).

\section{Antioxidative activity}

The antioxidant activity of the samples considering the stable DPPH (2.2-diphenyl-1-picryl-hydrazyl) radical was determined by the method of Liyana-Pathiranan and Shaidi [20]. Trolox solutions in the range of $0.25-4 \mu \mathrm{g} / \mathrm{mL}$ were used to make the calibration curve and the measuring wavelength was $515 \mathrm{~nm}$. The antioxidant activity of the samples considering the stable ABTS (2.2-Azinobis-(3-ethylbenzothiazoline6 -sulfonyl)-diammonium salt) radical was determined by the method of Re et al. [21]. Trolox solutions in the range of 1.25$10 \mu \mathrm{g} / \mathrm{mL}$ were used to make the calibration curve, and the measuring wavelength was $734 \mathrm{~nm}$. The ability of ethanol extracts to neutralize the hydroxyl radical was determined according to the method described in the literature [22]. The results of the antioxidant activity are presented as EC50 (the concentration of the extract or standard that has the ability to inhibit 50\% DPPH, ABTS and OH radicals) and TEAC value (Trolox Equivalent Antioxidant Activity for DPPH and ABTS radicals).

\section{Antihyperglycemic activity}

The influence of dry extracts of rosehips and wild grown pomegranate on the inhibition of the enzyme $\alpha$-glucosidase activity (antihyperglycemic effect) was determined by a modified method according to Chan et al. [23]. The method is based on measuring the increase in absorbance at the wavelength of $405 \mathrm{~nm}$, which originates from 4-nitrophenol released from 4-nitrophenyl- $\alpha$-D-glucopyranoside under the action of the enzyme $\alpha$-glucosidase after 20 minutes of incubation with and without the sample (control) on $37^{\circ} \mathrm{C}$. The results are presented as EC50.

Statistical data processing was performed in OriginPro 8.0 , and the results were presented as mean \pm standard deviation (SD) of three parallel measurements.

\section{Results and discussion}

The polyphenolic composition of wild grown rosehip and pomegranate samples is shown in Table 1. The content of total phenols in the rosehip sample was $8.75 \mathrm{mg} \mathrm{GAE} /$ $g_{F P M}$ which is higher compared to the results of other authors (from 2.57 to $8.13 \mathrm{mg}$ GAE/gFPM) [2, 24-26]. Murathan et al. [27] reported higher values of total phenols in different rosehip species, ranging from 10.81 to $62.98 \mathrm{mg} \mathrm{GAE} /$ $g_{F P M}$. The content of total flavonoids was $1.08 \mathrm{mg}$ Qc/g $\mathrm{g}_{\mathrm{FPM}}$, about 3 times higher than the content of total flavonoids that Cosmulescu et al. [2] found in Romanian wild grown rosehip. The content of total flavonols and flavan-3-ols was $0.057 \mathrm{mg}$ Qc/gFPM and $1.30 \mu \mathrm{g}$ CAT/gFPM, respectively. According to the obtained results (Table 1), the content of total phenols, flavonoids, flavonols and flavan-3-ols in rosehip are higher than the content of this compounds found in the pomegranate sample extracts. According to Cosmulescu et al. [2] these differences can be explained due to genetic factors and a different ability to synthesize the secondary metabolites of species. That ability of the plants was selected in their phylogenetic development process, and there are relevant differences with regard to the synthesis and accumulation of secondary metabolites within species.

The content of total phenols in the pomegranate sample was $3.44 \mathrm{mg} \mathrm{GAE} / \mathrm{g}_{\mathrm{FPM}}$. The content of total flavonoids, flavonols and flavan-3-ol was significantly lower than the content of total phenols (Table 1). The content of total anthocyanins in the pomegranate sample was $0.07 \mathrm{mg} \mathrm{CyG/}$ $g_{F P M}$ and the same content was found in cultivated pomegranate juice (cultivar 'Ruby') and wild grown pomegranate fruit in the literature data $[28,29]$. The dry matter content of 
the rosehip sample was $39.76 \%$. According to the literature data, the dry matter content in fruits of wild grown rosehip ranges from 20.5 to $56.7 \%$ [27, 30]. The pomegranate sample had $22.30 \%$ of the dry matter, slightly higher than the value $(19.60 \%)$ reported by Calín-Sánchez et al. [9].

Table 1. The content of total phenols (TP), flavonoids (TF), flavonols (TFI), flavan-3-ols (TFI3ol) and total (TA) and monomeric anthocyanins (MA) in wild grown rosehip and pomegranate samples expressed per gram of the fresh plant material

\begin{tabular}{lcccccc}
\hline Samples & $\begin{array}{c}\text { TP } \\
\mathrm{mgGAE} / \mathrm{g}\end{array}$ & $\begin{array}{c}\mathrm{TF} \\
\mathrm{mgQC} / \mathrm{g}\end{array}$ & $\begin{array}{c}\mathrm{TFI} \\
\mathrm{mgQC} / \mathrm{g}\end{array}$ & $\begin{array}{c}\mathrm{TFF} / 3 \mathrm{ol} \\
\mu \mathrm{CCAT} / \mathrm{g}\end{array}$ & $\begin{array}{c}\mathrm{TA} \\
\mathrm{mgCyG} / \mathrm{g}\end{array}$ & $\begin{array}{c}\mathrm{MA} \\
\mathrm{mgCy} / \mathrm{g}\end{array}$ \\
\hline Rosehip & $8.75 \pm 0.47$ & $1.08 \pm 0.04$ & $0.057 \pm 0.02$ & $1.30 \pm 0.08$ & $0.07 \pm 0.01$ & $0.03 \pm 0.01$ \\
Pomegrante & $3.44 \pm 0.23$ & $0.81 \pm 0.01$ & $0.019 \pm 0.01$ & $0.85 \pm 0.14$ & $0.07 \pm 0.01$ & $0.06 \pm 0.01$
\end{tabular}

Results are presented as mean \pm standard deviation $S D(n=3)$. GAE - gallic acid, Qc - quercetin hydrate, CAT - catechin, CyG - cyanidin-3-glucoside.

The polyphenolic composition of the wild grown rosehip and pomegranate samples expressed on the dry plant material is shown in Table 2. Expressed on the dry plant material, the content of total phenols of rosehip sample was lower in relation to the literature data $[5,6]$.

Table 2. The content of total phenols (TP), flavonoids (TF), flavonols (TFI), flavan-3-ols (TFI3ol) and total (TA) and monomeric anthocyanins (MA) in wild grown rosehip and pomegranate samples expressed per gram of the dry plant material

\begin{tabular}{lcccccc}
\hline Samples & $\begin{array}{c}\mathrm{TP} \\
\mathrm{mgGAE} / \mathrm{g}\end{array}$ & $\begin{array}{c}\mathrm{TF} \\
\mathrm{mgQc} / \mathrm{g}\end{array}$ & $\begin{array}{c}\mathrm{TFI} \\
\mathrm{mgQc} / \mathrm{g}\end{array}$ & $\begin{array}{c}\mathrm{TFI30} \\
\mu \mathrm{gCAT} / \mathrm{g}\end{array}$ & $\begin{array}{c}\mathrm{TA} \\
\mathrm{mgCyG} / \mathrm{g}\end{array}$ & $\begin{array}{c}\mathrm{MA} \\
\mathrm{mgCyG} / \mathrm{g}\end{array}$ \\
\hline & & & & & & \\
Rosehip & $22.01 \pm 1.19$ & $2.71 \pm 0.10$ & $0.14 \pm 0.05$ & $3.27 \pm 0.21$ & $0.18 \pm 0.03$ & $0.08 \pm 0.03$ \\
Pomegrante & $15.43 \pm 1.05$ & $3.63 \pm 0.10$ & $0.09 \pm 0.01$ & $3.81 \pm 0.63$ & $0.31 \pm 0.01$ & $0.27 \pm 0.02$ \\
\hline
\end{tabular}

Results are presented as mean \pm standard deviation $S D(n=3)$. GAE - gallic acid, Qc - quercetin hydrate, CAT - catechin, CyG - cyanidin-3-glucoside.

The total anthocyanins content of the rosehip sample, expressed on the dry plant material, was higher in relation to the value obtained by Murathan et al. [27]. According to the results of other authors, the content of total phenols of pomegranate fruit ranges from 4.92 to 7.57 mg GAE/gDPM $[9,31]$, which is lower than the content of total phenols in pomegranate presented in Table 2.

Table 3. Antioxidative activity of ethanolic extracts of wild grown rosehip and pomegranate samples

\begin{tabular}{|c|c|c|c|c|c|}
\hline \multirow{2}{*}{$\begin{array}{l}\text { Method } \\
\text { Samples }\end{array}$} & \multicolumn{2}{|c|}{ DPPH test } & \multicolumn{2}{|c|}{ ABTS test } & \multirow{2}{*}{$\begin{array}{c}\begin{array}{c}\text { Neutralization } \\
\text { of OH radicals }\end{array} \\
\begin{array}{c}E C_{50} \\
\mu \mathrm{g} / \mathrm{mL}\end{array}\end{array}$} \\
\hline & $\begin{array}{l}\mathrm{EC}_{50} \\
\mu \mathrm{g} / \mathrm{mL}\end{array}$ & $\begin{array}{l}\text { TEAC } \\
\mu \mathrm{mol} / \mathrm{g}\end{array}$ & $\begin{array}{l}\mathrm{EC}_{50} \\
\mu \mathrm{g} / \mathrm{mL}\end{array}$ & $\begin{array}{l}\text { TEAC } \\
\mu \mathrm{mol} / \mathrm{g}\end{array}$ & \\
\hline Rosehip & $995.99 \pm 49.8$ & $25.21 \pm 3.32$ & $197.89 \pm 9.89$ & $34.06 \pm 4.78$ & $94.17 \pm 1.7$ \\
\hline Pomegranate & $2918.52 \pm 1313$ & $9.06 \pm 1.20$ & $556.52 \pm 25.04$ & $14.99 \pm 1.98$ & $92.03 \pm 2.75$ \\
\hline
\end{tabular}

that inhibits $50 \%$ of the radical. TEAC - Trolox Equivalent Antioxidant Activity.

The antioxidant activity of rosehip and pomegranate fruit extracts, considering stable DPPH, ABTS and $\mathrm{OH}$ radicals is shown in Table 3 . Other authors found a higher antioxidant activity (DPPH) of rosehip expressed as the $\mathrm{EC}_{50}$ value $[5,24]$. On the other hand, the antioxidant activity (DPPH and ABTS) expressed as TEAC value
(Table 3) was higher than the antioxidant activity of rosehip reported by Demir et al. [5] and Cosmulescu et al. [2] .

The antioxidative activity of pomegranate present in Table 3 was lower than the antioxidative activity of pomegranate researched by other authors [9, 31]. According to the results of DPPH and ABTS tests presented as $\mathrm{EC}_{50}$ and as TEAC values, it can be concluded that the rosehip extract had a higher antioxidant activity than the pomegranate extract. At the same time, the rosehip sample had a higher content of polyphenolic components compared to the pomegranate sample (Table 1).

The effect of rosehip and pomegranate extracts on the neutralization of $\mathrm{OH}$ radicals was approximately equal (94.17 and $92.03 \mu \mathrm{g} / \mathrm{mL}$ ). Nadjpal [22] found higher values of methanol extracts of rosehip on the neutralization of $\mathrm{OH}$ radicals $(475 \mu \mathrm{g} / \mathrm{mL})$, indicating a lower antioxidant activity compared to the antioxidant activity of the samples tested in this study.

The number of people suffering from hyperglycemia and diabetes is increasing worldwide. The inhibition of carbohydrate digestive enzymes by dietary phenolics may represent a mechanism for delivering some of the health benefits attributed to a diet rich in fruits [32].

The dry extract of the rosehip fruit sample showed about the 1.6 times better antihyperglycemic activity compared to the dry extract of the pomegranate fruit sample (Figure 1). Also, the content of total phenols in the rosehip fruit is about 1.4 times higher than the content of total phenols in the pomegranate fruit (expressed on the dry plant material of the sample, Table 2), based on which it can be assumed that the concentration of total phenols directly affects the inhibition of the a-glucosidase enzyme activity. Kunyanga et al. [33] found that food ingredients (cereals, legumes and oil seeds) with a high phenolic content exhibited relatively higher antioxidant and antihyperglycemic activities.

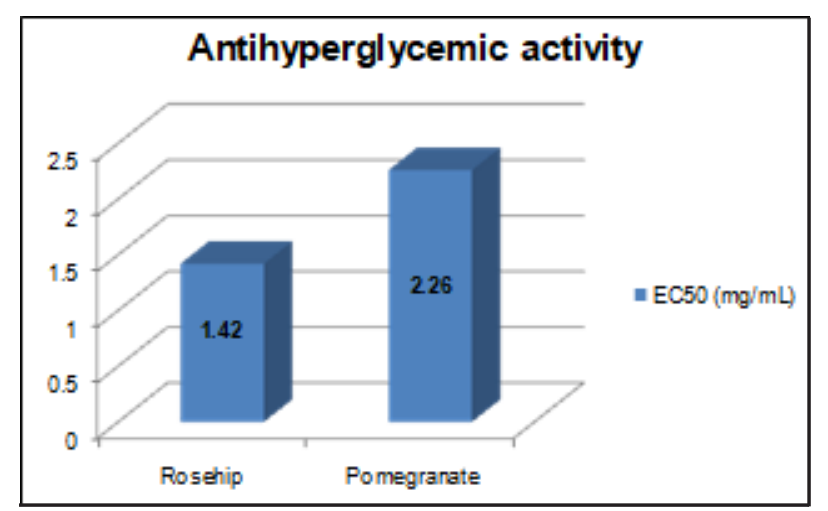

Figure 1. Antihyperglycemic activity of dry ethanolic extracts of wild grown rosehips and pomegranate fruits. EC50 values were obtained from the diagram: antihyperglycemic activity in relation to the concentration (wild rosehip/pomegranate).

Both samples showed a higher antihyperglycemic activity compared to aqueous extracts of edible parts of mandarin orange, apple, watermelon and grapefruit, but 
lower compared to the mulberry fruit ethanol extract [11, 34].

\section{Conclusion}

The results of this study indicate a significant antioxidant and antihyperglycemic activity of ethanolic extracts of wild grown rosehip and pomegranate. Among the investigated fruits, the rosehip with a higher content of phenolic components exhibited a relatively higher antioxidant as well as antihyperglycemic activity. The content of total phenols in the rosehip fruit was about 1.4 times higher than the content of total phenols in the pomegranate fruit, and it can be assumed that the concentration of total phenols directly affects the inhibition of the a-glucosidase enzyme activity. The content of total phenols in rosehip and pomegranate fruits was significantly higher than the content of total flavonoids, flavonols and flavan-3-ol and total and monomeric anthocyanins, which indicates that these components had the greatest impact on bioactivity of wild grown fruits. Due to their bioactivity, the fruits of wild grown rosehip and pomegranate can be considered as potential functional food and food suitable for diabetics.

\section{Abbreviations and symbols}

FPM - Fresh Plant Material

DPM - Dry Plant Material

GAE - Gallic Acid Equivalent

QC - quercetin hydrate

CAT - catechin

CyG - cyanidin-3-glucoside

DPPH - 2.2-diphenyl-1-picryl-hydrazyl

ABTS - 2.2-Azinobis-(3-ethylbenzothiazoline-6-sulfonyl)diammonium salt

TROLOX - 6-hydroxy-2,5,7,8-tetramethyl-chroman- 2carboxylic acid

TEAC - Trolox Equivalent Antioxidative Activity

\section{References}

[1] S. Parashar, H. Sharma, M. Garg, Antimicrobial and antioxidant activities of fruits and vegetable peels: A review, Journal of Pharmacognosy and Phytochemistry, 3(1) (2014) 160-164.

[2] S. Cosmulescu, I. Trandafir, V. Nour, Phenolic acids and flavonoids profiles of extracts from edible wild fruits and their antioxidant properties, International Journal of Food Properties, 20(12) (2017) 3124-3134.

[3] J. Concha, C. Soto, R. Chamy, M. E. Zuniga, Effect of rosehip extraction process on oil and defatted meal physicochemical properties, Journal of the American Oil Chemists' Society, 83(9) (2006) 771-775.

[4] S. Ercisli, Chemical composition of fruits in some rose (Rosa spp.) species, Food Chemistry, 104(4) (2007) 1379-1384.

[5] N. Demir, O. Yildiz, M. Alpaslan, A. A. Hayaloglu, Evaluation of volatiles, phenolic compounds and antioxidant activities of rose hip (Rosa L.) fruits in Turkey, LWT - Food Science and Technology, 57(1) (2014) 126-133.

[6] N. Koczka, É. Stefanovits-Bányai, A. Ombódi, Total polyphenol content and antioxidant capacity of rosehips of some rosa species, Medicines (Basel, Switzerland), 5(3) (2018) 84-94.

[7] D. Paunović, A. Kalušević, T. Petrović, T. Urošević, D. Djinović, V. Nedović, J. Popović-Đorđević, Assessment of chemical and antioxidant properties of fresh and dried rosehip (Rosa canina L.), Not Bot Horti Agrobo, 47(1) (2019) 108-113.

[8] H. Singh, N. Singh, A. Marathe, J. Ugalat, Influence of aril browning on biochemical properties of pomegranate (Punica granatum L.), Journal of Crop and Weed, 9(1) (2013) 184-187.

[9] Á. Calín-Sánchez, A. Figiel, F. Hernández, P. Melgarejo, K. Lech, Á. A. Carbonell-Barrachina, Chemical composition, antioxidant capacity, and sensory quality of pomegranate (Punica granatum L.) arils and rind as affected by drying method, Food and Bioprocess Technology, 6(7) (2012) 1644-1654.

[10] F. Alam, Z. Shafique, S. T. Amjad, M. H. H. Bin Asad Enzymes inhibitors from natural sources with antidiabetic activity: A review, Phytotherapy Research, 33(1) (2019) 41-54.

[11] Y. Kawada, M. Miura, T. Gomyo, Inhibitory effect of vegetables, fruits and herbs on a-glucosidase in an immobilized enzyme assay system, Food Science and Technology Research, 12(4) (2006) 275-277.

[12] S. Y. Jeon, S. Oh, E. Kim, J. Y. Imm, a-Glucosidase inhibiton and antiglycation activity of laccase-catalyzed catechin polymers, Journal of Agricultural and Food Chemistry, 61(19) (2013) 4577-4584.

[13] L. Zhang, J. Li, S. Hogan, H. Chung, G. E. Welbaum, K Zhou, Inhibitory effect of raspberries on starch digestive enzyme and their antioxidant properties and phenolic composition, Food Chemistry, 119(2) (2010) 592-599.

[14] K. Wolfe, X. Wu, R. H. Liu, Antioxidant activity of apple peels, Journal of Agricultural and Food Chemistry, 51(3) (2003) 609-614.

[15] E. A. Ordon, J. D. Gomez, M. A. Vattuone, M. I. Isla, Antioxidant activities of Sechium edule (Jacq.) swart extracts, Food Chemistry, 97(3) (2006) 452-458.

[16] A. Kumaran, R. J. Karunakaran, In vitro antioxidant activities of methanol extracts of Phyllanthus species from India, LWT - Food Science and Technology, 40(2) (2007) 344-352

[17] E. Revilla, E. Alonso, M. Burzeix, N. Heredia, Dosage des catéchines et des proanthocyanidols dans les vins, Bull. O. I. V. F. V. 829, (1991).

[18] M. M. Giusti, R. E. Wrolstad, in Current Protocols in Food Analytical Chemistry, R. E. Wrolstad Ed., John Wiley \& Sons, Hoboken 2001, p. F.1.2.1-13.

[19] AOAC Official Method 925.09. Solids (Total) and Moisture in Flour. 18th edition. Gaithersburg, AOAC International, 2005.

[20] C. Liyana-Pathiranan, F. Shahidi, Antioxidant activity of commercial soft and hard wheat (Triticum aestivum L.) as affected by gastric $\mathrm{pH}$ conditions, Journal of Agriculture and Food Chemistry, 53(7) (2005) 2433-2440.

[21] R. Re, N. Pellegrini, A. Proteggente, A. Pannala, M. Yang, C. Rice-Evans, Antioxidant activity applying an improved ABTS radical cation decolorization assay, Free Radical Biology and Medicine, 26(9-10) (1999) 1231-1237

[22] J. Nadjpal, Fitohemijski skrining i biološka aktivnost ekstrakata i tradicionalnih proizvoda od plodova divljih ruža (Rosa L.; Rosaceae). Thesis, Faculty of Technology, 
University of Novi Sad, 2017.

[23] H. H. Chan, H. D. Sun, M. V. B. Reddy, T. S. Wu, Potent a-glucosidase inhibitors from the roots of Panax japonicus C. A. Meyer var. major, Phytochemistry, 71(11-12) (2010) 1360-1364.

[24] L. Su, J. J. Yin, D. Charles, K. Zhou, J. Moore, L. Yu, Total phenolic contents, chelating capacities, and radicalscavenging properties of black peppercorn, nutmeg, rosehip, cinnamon and oregano leaf, Food Chemistry, 100(3) (2007) 990-997.

[25] I. Egea, P. Sánchez-Bel, F. Romojaro, M. T. Pretel, Six edible wild fruits as potential antioxidant additives or nutritional supplements, Plant Foods for Human Nutrition, 65(2) (2010) 121-129.

[26] J. Smanalieva, J. Iskakova, Z. Oskonbaeva, F. Wichern, D. Darr, Investigation of nutritional characteristics and free radical scavenging activity of wild apple, pear, rosehip, and barberry from the walnut-fruit forests of Kyrgyzstan, European Food Research and Technology, 246 (2020) 1095-1104.

[27] Z. T. Murathan, M. Zarifikhosroshahi, N. E. Kafkas, Determination of fatty acids and volatile compounds in fruits of rosehip (Rosa L.) species by HS-SPME/GC-MS and Im-SPME/GC-MS techniques, Turkish Journal of Agriculture and Forestry, 40(2) (2016) 269-279.

[28] L. O'Grady, G. Sigge, O. J. Caleb, U. L. Opara, Bioactive compounds and quality attributes of pomegranate arils (Punica granatum L.) processed after long-term storage, Food Packaging and Shelf Life, 2(1) (2014) 30-37.

[29] N. S. Thakur, M. M. Bhat, N. Rana, V. K. Joshi, Standardization of pre-treatments for the preparation of dried arils from wild pomegranate, Journal of Food Science and Technology, 47(6) (2010) 620-625.
[30] F. Demir, M. Özcan, Chemical and technological properties of rose (Rosa canina L.) fruits grown wild in Turkey, Journal of Food Engineering, 47(4) (2001) 333336.

[31] D. Z. Lantzouraki, V. J. Sinanoglou, P. Zoumpoulakis, C. Proestos, Comparison of the antioxidant and antiradical activity of pomegranate (Punica granatum L.) by ultrasound-assisted and classical extraction, Analytical Letters, 49(7) (2015) 969-978.

[32] K. Arun, P. Jayamurthy, C. Anusha, S. Mahesh, P. Nisha, Studies of acitivity guided fractional of pomegranate peel extracts and its effect on antidiabetic and cardiovascular protection properties, Journal of Food processing and Preservation, 41(1) (2016) 1-12.

[33] C. N. Kunyanga, J. K. Imungi, M. W. Okoth, H. K. Biesalski, V. Vadivel, Total phenolic content, antioxidant and antidiabetic properties of methanolic extract of raw and traditionally processed Kenyan indigenous food ingredients, LWT - Food Science and Technology, 45 (2012) 269-276.

[34] Y. Wang, L. Xiang, C. Wang, C. Tang, X. He, Antidiabetic and antioxidant effects and phytochemicals of mulberry fruit (Morus alba L.) polyphenol enhanced extract, PLoS One, 8(7) (2013).

\section{Izvod \\ POTENCIJALNA BIOAKTIVNOST PLODOVA SAMONIKLOG ŠIPKA (Rosa canina L.) I NARA (Punica granatum L.)}

Staniša Latinović, Mirjana Brkljača, Marina Vujasin, Zoran Kukrić, Božana Odžaković

Tehnološki fakultet, Univerzitet u Banjoj Luci, Banja Luka, Bosna i Hercegovina

Cilj rada bio je određivanje antioksidativnog i antihiperglikemijskog efekta etanolnih ekstrakata ploda samonikolog šipka i nara, kao i određivanje sadržaja ukupnih fenola, flavonoida, flavonola, flavan-3-ola, ukupnih i monomernih antocijana u ispitivanim plodovima. Antioksidativna aktivnost ploda šipka na stabilne DPPH i ABTS radikale bila je veća u odnosu na plod nara, dok su prema $\mathrm{OH}$ radikalu ova dva uzorka pokazala sličan efekat $(94,17$ i $92,03 \mu \mathrm{g} / \mathrm{mL})$. Ustanovljeno je da suvi ekstrakt ploda šipka ima 1,6 puta izraženije antihiperglikemijsko delovanje $(1,42 \mathrm{mg} / \mathrm{mL}) \mathrm{u}$ odnosu na suvi ekstrakt ploda nara $(2,26 \mathrm{mg} / \mathrm{mL})$. Sadržaj ukupnih fenola u plodovima šipka i nara, izražen na masu svežeg biljnog materijala, iznosio je 8,75 mg GAE/g i 3,44 mg GAE/g, respektivno, odnosno 22,01 mg GAE/g i 15,43 mg GAE/g, na suvu materiju biljnog materijala. Sadržaj ukupnih fenola u plodovima šipka i nara bio je veći od sadržaja ukupnih flavonoida, flavonola i flavan-3-ola kao i ukupnih i monomernih antocijana, što ukazuje da su ove komponente imale najveći uticaj na bioaktivnost samoniklih plodova. Zbog utvrđene bioaktivnosti, plodovi samoniklog šipka i nara mogu se smatrati potencijalnom funkcionalnom hranom i hranom pogodnom za dijabetičare.
(ORIGINALNI NAUČNI RAD) UDK 547.565:615.322:616.379-008.64 DOI: $10.5937 /$ savteh2002014L

Ključne reči: polifenolne komponente, antioksidativnost, antihiperglikemijsko dejstvo 